\title{
Effect of Organic, Inorganic and Bio-Fertilizers on Growth, Yield and Quality Traits of Okra [Abelmoschus esculentus (L.) Moench]
}

\author{
Singh Smriti ${ }^{1 *}$ and R.B. Ram $^{2}$ \\ Department of Horticulture, Babasaheb Bhimrao Ambedkar University (A central university) \\ Vidya - vihar Rae-bareli Road Lucknow-226025, India \\ *Corresponding author
}

\section{A B S T R A C T}

The present experiment was carried out at the Horticulture Research Farm of the Department of Horticulture, Babasaheb Bhimrao Ambedkar University, Lucknow, Uttar Pradesh, India during the year 2016-1017. The plant to plant and row to ro spacing were maintained at 30x60 cm respectively. The experiment was carried under Randomized Block Design (RBD) with three replications. A single standard variety (kashipragati) released from IIVR Varanasi is sown with the different treatment combinations. The treatment combinations were T1 control, T2 (FYM), T3 (Vermicompost), T4 Neemcake, $\mathrm{T} 5$ (50\% RDF+FYM), T6 (50\%RDF+ Vermicompost) T7 (50\%RDF+Neemcake), T8 (75\% RDF+FYM), T9 (75\%RDF+Vermicompost), T10 (75\%RDF+Neemcake), T11 (50\%RDF+Azotobacter), $\quad$ T12 (50\%RDF+PSB), $\quad$ T13 (50\%RDF+VAM), $\quad$ T14 (75\%RDF+Azotobacter), T15 (75\%RDF+PSB), T16 (5\%RDF+VAM). On the basis of overall performance under the present investigation, it may be concluded that the application of 50\%RDF+Vermicompost in kasha pragati increased the growth, yield and nutritional quality of okra under Lucknow condition.

\section{Introduction}

Okra [Abelmoschus esculentus L. (Moench)], is an economically important vegetable crop grown in tropical and sub-tropical parts of the world. It is generally an annual plant. Okra belongs to genus Abelmoschus and species esculentus of family Malvaceae. It is also known as lady's finger or bhindi, originated in tropical Africa. Because of its richness in nutrition, taste, medicinal and industrial value okra is one of the most popular vegetables in all section of people. Okra is cultivated for its fibrous fruits or pods containing round, white seeds. The fruits are harvested when immature and eaten as a vegetable. Okra is mainly propagated by seeds and has duration of 90100 days. Okra can be grown in both the seasons i.e., Rabi and Kharif. Okra requires a long, warm and humid growing period. Okra is a good source of vitamins, minerals, calories, and amino acid found in seeds and compares favourably with those in poultry, eggs and soyabean, (Thompson, 1949; Schipper, 2000). All parts of okra (Ladies' fingers) likes fresh leaves, buds, flowers, pods, stems and seeds can be used for different purpose and hence it is a multipurpose crop in 
term of its use (Gemede et al., 2015). The mucilage found in okra may be used for plasma replacement or blood expender (Madison, 2008 and Maramag, 2013). Moreover, long term sustainability of productivity could be achieved only through the interaction of inorganic and organic sources of nutrients (Hedge et al., 1992 and Singh and Yadav, 1992). In India, Uttar Pradesh covering an area of 11.10 thousand hectares with a production of 128.80 thousand million tonnes and productivity of 11.31 metric tonnes per hectare (Anonymous, 2011). Indiscriminate use of inorganic fertilizers has resulted in decreased nutrient uptake, poor quality of vegetables and deterioration of soil health (Ganesh et al., 2000; Agrawal, 2003). Okra produces fruit for a long time and needs balanced and sufficient supply of nutrients for higher yield and better quality.

\section{Materials and Methods}

An experiment was conducted at Horticulture Research Farm, Department of Horticulture, at Babasaheb Bhimrao Ambedkar University, Lucknow during September to December of 2016. The experiment was laid out in randomized block design with 16 treatments replicated thrice. Total numbers of plots were 48 and the net plot size was $\left(3.6 \mathrm{~m}^{2}\right)$. The row to row and plant to plant distance of the experiment was maintained respectively $60 \mathrm{~cm}$ and $30 \mathrm{~cm}$. The treatments involved were $T 1$ (Control), T2 (FYM/Compost), T3 (Vermicompost), T4 (Neemcake), T5 (50\% RDF+FYM/Compost), $\quad$ T6 (50\% $\quad$ RDF+ Vermicompost), T7 (50\% RDF+Neemcake), T8 (75\% RDF+FYM/Compost), T9 (75\% RDF+Vermicompost), $\quad$ T10 $\quad(75 \% \quad \mathrm{RDF}+$ Neemcake), T11 (50\%RDF+Azotobacter), T12 (50\% RDF+PSB), T13 (50\% RDF+VAM), T14 (75\%RDF+Azotobacter), T15 (75\% RDF+ PSB) and T16 (75\%RDF+ VAM). The land was brought to a fine tilth through ploughing and tillage. Irrigation channels and bunds were maintained properly. The seeds were sown directly to the field. Light irrigation was given after sowing. The organic manures were applied as basal dose before sowing, for proper decomposition, full dose of phosphorus and potassium and half dose of nitrogen as per treatment were applied just before the sowing. The remaining half dose of nitrogen was applied 30 days after sowing. All cultural practices were followed regularly during crop growth and observations were recorded on vegetative characters i.e. days to germination $(50 \%)$, days to germination $(100 \%)$, plant height, stem diameter, number of branches per plant, number of leaves, number of nodes per plant, internodal length. flowering, fruiting and yield characters i.e. days to first flowering, days to $50 \%$ flowering, number of fruits per plant, fruit weight, fruit length, fruit diameter, days to first picking, fruit yield per plant, fruit yield per hectare, number of seeds per fruits and bio-chemical parameters i.e. total soluble solids ( ${ }^{0}$ Brix), ascorbic acid, reducing sugar, non-reducing sugar and total sugars. The data on these parameters were subjected to statistical analysis to draw logical conclusions.

\section{Results and Discussion}

The perusal data (Table 1) of result indicated that okra plants fertilized with integrated nutrient management T11 (50\% $\mathrm{RDF}+$ Azotobactor) and T9 $(75 \%$ RDF+ Vermicompost) gave maximum plant heights respectively i.e., $(75.08 \mathrm{~cm})$ and (88.41). Maximum number of leaves 9.83 and 17.33 found in T8 (75\% RDF+ FYM) followed by T5 (50\% RDF+ FYM) respectively. T9 (75\% RDF+ Vermicompost), T9 (75\% RDF+Vermicompost), and T6 (50\% $\mathrm{RDF}+$ Vermicompost) gave maximum results in maximum number of nodes respectively $8.91,14.00,23.91$ and maximum number of branches have been observed in the treatments respectively (3.75) T6 (50\% RDF+ Vermi 
compost), (6.5) T14 (75\%RDF+Azotobacter), (12.41) T14 (75\%RDF+Azotobacter). Highest Internodal length $9.29(\mathrm{~cm})$ was found in T11 (50\% RDF +Azotobactor). Treatment T16 $(75 \% \mathrm{RDF}+\mathrm{VAM})$ results in minimum days to $50 \%$ germination and $\mathrm{T} 16(75 \% \mathrm{RDF}+\mathrm{VAM})$ required minimum days to $100 \%$ germination (18.66 days) and also results in maximum stem diameter $(11.11 \ldots .$.$) . Organic manures$ helps in improving soil health and it ensures proper aeration in soil and improves water holding capacity of soil. All over the study of vegetative characters it was observed that half dose of organic and inorganic fertilizers perform better instead of sole application of chemical fertilizer. Similarly, Minimum days to first flowering under the Treatment T16 (75\% RDF+VAM) was observed 91.33. and days to $50 \%$ flowering 46.83 under the treatment T16 (75\%RDF+VAM) was recorded (Table 1).

Table.1 Effect of organic, inorganic, and biofertilizers on growth, yield and Quality traits of okra cultivar

\begin{tabular}{|c|c|c|c|c|c|c|c|c|}
\hline Treatments & $\begin{array}{l}\text { Days to } \\
\text { germination } \\
50 \%\end{array}$ & $\begin{array}{l}\text { Days to } \\
\text { germination } \\
100 \%\end{array}$ & $\begin{array}{l}\text { Plant } \\
\text { height }\end{array}$ & $\begin{array}{l}\text { Stem } \\
\text { diameter }\end{array}$ & $\begin{array}{l}\text { No of } \\
\text { Branches } \\
\text { per plant }\end{array}$ & $\begin{array}{l}\text { No of } \\
\text { Leaves }\end{array}$ & $\begin{array}{l}\text { No of } \\
\text { nodes } \\
\text { per } \\
\text { plant }\end{array}$ & $\begin{array}{l}\text { Internodal } \\
\text { length }\end{array}$ \\
\hline $\mathrm{T1}$ & 7.33 & 14.00 & 47.15 & 9.71 & 9.67 & 15.33 & 15.95 & 6.80 \\
\hline $\mathrm{T2}$ & 8.11 & 15.33 & 48.87 & 10.04 & 13.22 & 15.93 & 16.50 & 7.03 \\
\hline $\mathrm{T3}$ & 7.90 & 14.33 & 50.80 & 10.51 & 10.83 & 16.67 & 17.26 & 7.36 \\
\hline $\mathrm{T} 4$ & 8.50 & 15.00 & 57.82 & 12.05 & 10.20 & 19.18 & 19.79 & 8.44 \\
\hline $\mathrm{T5}$ & 8.00 & 15.66 & 58.25 & 12.13 & 10.65 & 19.25 & 19.93 & 8.49 \\
\hline T6 & 7.67 & 15.00 & 87.15 & 13.55 & 15.93 & 25.20 & 22.25 & 9.50 \\
\hline $\mathrm{T} 7$ & 7.69 & 14.00 & 60.72 & 11.11 & 9.88 & 19.82 & 18.25 & 7.78 \\
\hline $\mathrm{T} 8$ & 8.10 & 15.00 & 61.86 & 11.63 & 10.51 & 20.46 & 19.11 & 8.14 \\
\hline T9 & 8.00 & 14.66 & 62.53 & 11.77 & 10.86 & 20.67 & 19.33 & 8.25 \\
\hline T10 & 7.10 & 15.00 & 63.50 & 11.96 & 12.45 & 20.95 & 19.65 & 8.38 \\
\hline T11 & 7.90 & 15.66 & 63.79 & 12.07 & 12.80 & 21.05 & 19.83 & 8.45 \\
\hline T12 & 7.88 & 16.66 & 72.29 & 12.61 & 8.23 & 23.05 & 20.72 & 8.83 \\
\hline T13 & 8.12 & 14.33 & 74.34 & 12.86 & 14.10 & 23.29 & 21.12 & 9.01 \\
\hline T14 & 8.00 & 16.66 & 76.90 & 12.97 & 8.58 & 23.58 & 21.31 & 9.08 \\
\hline T15 & 8.25 & 16.33 & 82.14 & 13.08 & 9.92 & 23.80 & 21.65 & 9.15 \\
\hline T16 & 7.90 & 18.66 & 57.68 & 11.91 & 7.91 & 18.78 & 19.56 & 8.34 \\
\hline S.E (d) & 0.71 & 1.69 & 1.99 & 0.63 & 0.61 & 1.06 & 1.14 & 0.35 \\
\hline C.D & N.S. & N.S. & 4.07 & 1.31 & 1.25 & 2.17 & 2.33 & 0.71 \\
\hline
\end{tabular}


Table.2 Effect of organic, inorganic, and biofertilizers on growth, yield and Quality traits of okra cultivar

\begin{tabular}{|c|c|c|c|c|c|c|c|c|c|c|}
\hline Treatments & $\begin{array}{l}\text { Days to } \\
\text { first } \\
\text { flowering }\end{array}$ & $\begin{array}{l}\text { Days to } \\
50 \% \\
\text { flowering }\end{array}$ & $\begin{array}{l}\text { NO Of } \\
\text { fruits } \\
\text { per } \\
\text { plant }\end{array}$ & $\begin{array}{l}\text { Fruit } \\
\text { weight }\end{array}$ & $\begin{array}{l}\text { Fruit } \\
\text { length }\end{array}$ & $\begin{array}{l}\text { Fruit } \\
\text { diameter }\end{array}$ & $\begin{array}{l}\text { Days } \\
\text { to first } \\
\text { picking }\end{array}$ & $\begin{array}{l}\text { Fruit } \\
\text { yield } \\
\text { per } \\
\text { plot }\end{array}$ & $\begin{array}{l}\text { Fruit } \\
\text { yield } \\
\text { q/ha }\end{array}$ & $\begin{array}{l}\text { No. of } \\
\text { seeds } \\
\text { per } \\
\text { fruits }\end{array}$ \\
\hline T1 & 34.50 & 39.40 & 15.33 & 28.90 & 13.20 & 16.69 & 47.10 & 0.05 & 158.98 & 50.33 \\
\hline $\mathrm{T} 2$ & 35.67 & 40.70 & 15.91 & 29.99 & 13.70 & 17.32 & 48.88 & 0.05 & 165.37 & 52.23 \\
\hline T3 & 37.35 & 42.60 & 16.59 & 31.27 & 14.28 & 18.06 & 50.97 & 0.06 & 172.68 & 57.79 \\
\hline $\mathrm{T4}$ & 42.80 & 46.80 & 19.04 & 35.89 & 16.39 & 19.72 & 58.50 & 0.07 & 199.16 & 59.47 \\
\hline T5 & 43.05 & 47.10 & 19.16 & 36.10 & 16.49 & 19.85 & 58.87 & 0.07 & 199.35 & 59.86 \\
\hline T6 & 45.40 & 49.80 & 25.78 & 45.60 & 20.83 & 24.35 & 60.21 & 0.11 & 320.74 & 70.43 \\
\hline T7 & 37.50 & 42.80 & 19.77 & 37.27 & 17.02 & 21.52 & 58.74 & 0.07 & 205.55 & 63.89 \\
\hline T8 & 39.30 & 43.80 & 20.42 & 38.50 & 17.58 & 22.22 & 59.73 & 0.07 & 212.12 & 65.01 \\
\hline T9 & 39.80 & 44.10 & 20.62 & 38.85 & 17.74 & 22.43 & 57.88 & 0.07 & 214.45 & 65.64 \\
\hline T10 & 40.50 & 45.25 & 20.95 & 39.50 & 18.04 & 22.80 & 57.95 & 0.07 & 217.79 & 66.75 \\
\hline T11 & 40.85 & 45.90 & 21.05 & 39.70 & 18.13 & 22.92 & 57.15 & 0.07 & 218.61 & 67.12 \\
\hline T12 & 42.70 & 46.75 & 23.80 & 43.85 & 20.03 & 23.33 & 57.80 & 0.08 & 250.83 & 68.35 \\
\hline T13 & 43.70 & 47.40 & 24.46 & 44.10 & 20.14 & 23.46 & 58.20 & 0.08 & 257.68 & 68.75 \\
\hline T14 & 44.10 & 48.10 & 24.70 & 44.55 & 20.35 & 23.73 & 58.44 & 0.08 & 266.29 & 69.56 \\
\hline T15 & 44.40 & 48.40 & 24.90 & 44.90 & 20.51 & 23.93 & 58.65 & 0.09 & 283.98 & 69.65 \\
\hline T16 & 40.30 & 44.10 & 18.79 & 35.40 & 16.17 & 20.45 & 56.73 & 0.06 & 194.723 & 61.67 \\
\hline S.E (d) & 0.89 & 0.97 & 0.92 & 1.45 & 0.86 & 0.81 & 1.32 & 0.00 & 24.13 & 2.65 \\
\hline C.D & 1.82 & 1.98 & 1.89 & 2.97 & 1.76 & 1.65 & 2.70 & 0.01 & 49.31 & 5.41 \\
\hline
\end{tabular}

Minimum days to first picking (48.91) under the treatment $\mathrm{T} 13$ (50\%RDF+VAM) and, maximum number of fruits per plant was recorded (18.16) under T6 (50\%RDF+ Vermicompost), highest yield per plot in T6 (50\%RDF +Vermicompost) as well as yield per hectare was recorded respectively 11.42 , 31740.73 , best fruit weight is 44.08 in $\mathrm{T} 13$ (50\%RDF+VAM), likewise highest fruit length is 13.27 under the treatment T2 (FYM) and fruit diameter gave maximum no of data i.e. 16.68 in $\mathrm{T} 1$, and the last data no of seeds per fruit gave the maximum no of seeds is 64.08 under the treatments $\mathrm{T} 5$ (50\%RDF+FYM) and $\mathrm{T} 10$ (75\%RDF+Neemcake). Study analyses the best result of T6 in the whole experiment. The plant height and number of leaves, which were significantly higher when compared to glyricidia, FYM, poultry manure and vermicompost application alone
(Channabasangowda et al., 2008; Mojeremane et al., 2015).

This response may be due to better nutrient availability and its uptake by the plants (Roy and Singh, 2006; Achsah and Lakshmi Prabha, 2013). The variation in number of leaves and leaf area by the application of chemical fertilizer were also observed by Arora 1991, and Somkuwar (1997). Rajkhowa et al., (2003) also found significant increase in nutrient uptake by combine use of fertilizer along with vermicompost. Manna et al., (2005) [6] reported that integrated nutrient management, including NPK improved soil organic carbon as well as crop productivity in different agroecosystems. Farmyard manure has been used as a soil conditioner since ancient times and its benefit have not been fully harnessed due to large quantities required in order to satisfy the 
nutritional needs to crops (Makinde et al., 2007; Pennington et al., 2015 The primary goal of organic farming is to optimize the health and productivity of interdependent communities of soil life, plants, animals and people (Yuda et al., 2016).

Thus on the basis of present investigation, it could be concluded that the okra var. KashiPragati responded well in terms of growth, yield and net profit by the application of (50\%RDF+Vermicompost) for highest yield per plot as well as yield per/ha.

\section{References}

Anonymous (2017) Integrated Nutrient Management (INM) in Okra (Abelmoschus esculentus (L.) Moench) for BetterGrowth and Higher Yield. Journal of Pharmacognosy and Phytochemistry 6 (5): 1854-1856

Channabasangowda et al., (2008); Mojeremane et al., (2015) Effect of Organic fertilizers on the Growth and Biochemical Characteristics of Okra (Abelmoschus esculentus (L.) Moench) International Journal of Science and Research (IJSR)

Gemede et al., (2015). Growth and yield attribute of okra (Abelmoschus esculentus L.) under the application of bio and chemical fertilizers either alone or in combination. International Journal of Agricultural Science and Research (IJASR).6 (1): 189-198.

Hedge et al., (1992) and Singh and Yadav, (1992).Effect of integrated nutrient management on growth, yield, and quality of okra (Abelmoschus esculentus (L).
Moench) cv. ArkaAnamika International Journal of Chemical Studies 2017; 5 (5): 2001-2003

Madison D. (2008) and Maramag, R.P. (2013) Growth and yield attribute of okra (Abelmoschus esculentus) under the application of bio and chemical fertilizers either alone or in combination. International Journal of Agricultural Science and Research (IJASR) 6 (1):189198

Makindeet al., (2007) and Pennington et al., (2015) Effect of organic fertilizers on the growth and biochemical characteristics of Okra (Abelmoschus esculentus (L.) Moench) International Journal of Science and Research (IJSR)

Manna et al., (2017) Effect of integrated nutrient management on growth, yield, and quality of okra (Abelmoschus esculentus (L).Moench) cv. ArkaAnamika International Journal of Chemical Studies 5 (5): 2001-2003

Rajkhowaet al., (2003) Effect of INM on nutrient uptake, yield and quality of okra [Abelmoschus esculents (L.) Moench] An Asian Journal of Soil Science. 9 (1):21-24

Roy and Singh (2006) Achsah and Lakshmi Prabha (2013).Effect of Organic fertilizers on the Growth and Biochemical Characteristics of Okra (Abelmoschus esculentus (L.) Moench) International Journal of Science and Research (IJSR)

Yudaet al., (2016) Effect of Organic fertilizers on the Growth and Biochemical Characteristics of Okra (Abelmoschus esculentus (L.) Moench). International Journal of Science and Research (IJSR).

\section{How to cite this article:}

Singh Smriti and Ram, R.B. 2018. Effect of Organic, Inorganic and Bio-Fertilizers on Growth, Yield and Quality Traits of Okra [Abelmoschus esculentus (L.) Moench]. Int.J.Curr.Microbiol.App.Sci. 7(04): 2388-2392. doi: https://doi.org/10.20546/ijcmas.2018.704.274 